Ewelina Wojciechowska

Nicolaus Copernicus University in Torun (Poland)

\title{
Challenging Life Nearby Russia
}

Book Review: Sylwester Gardocki (Ed.), Rosja i jej sasiedzi. Studia i szkice. Wydawnictwo Adam Marszałek: Toruń 2015. ISBN: 978-83-8019-208-9.

For the attention of both practitioners and theoreticians dealing with the East European politics deserves the most recent book edited by Sylwester Gardocki, Rosja i jej sasiedzi. Studia $i$ szkice. The book, composed of eleven articles, refers to a large extent to certain aspects of political, social and economic relations of the Russian Federation with its closest neighbours. It discusses Russian-British, Russian-Ukrainian and mutual political relations within the European Union and between the Eastern Partnership countries or Baltic countries.

This volume is a continuation of the considerations contained in the previous collective work, namely: Russia, Ukraine, Belarus. Selected dilemmas of development (Torun 2013) and The area of the former Soviet Union. The failure of democracy or transformation? (Torun 2013). Sylwester Gardocki is a professor of political science, a lawyer and lecturer at the Institute of International Relations at the University of Warsaw. His research interests, as a result of his numerous academic achievements, focus on politico-legal Russian Federation. In his publications he also writes on historical and social issues.

It can be assumed that this publication is a continuation of the considerations of the editor of the book. In the first chapter, he introduces the reader to the discussed topics. The author analyses the cultural context conditioning the development of nineteenth-century Russian politico-legal thought. He points out to the evolution of the thought in the modern era relating to beaten cultural habits and national myths. Highly interesting is to show the myth of Russia's wild, unpredictable and insidious, which then is compared with the myth of Europe, as that which has represented maturity, prudence and harmony. France is refered toas an ageing country and thus perceived as a well organised and internally consistent, while Russia as a young country - appears to be a giant, but uncouth, internally broken, unpredictable. These and other concepts are interesting because most of them are still valid. 
The text reminds us how deeply rooted myths and mutual ideas have an impact on everyday practical policy pursued by various countries.

Various political issues relating to Russia and its neighbours are presented in the following ten chapters. The considerations of their authors refer to countries such as Ukraine, Belarus, Lithuania, Latvia and Estonia, the other countries of the European Union, as well as the area of Central Asia. Articles do not refer only to the interests of Russia, as can be inferred from the title of the book, but they are only a starting point for deeper reflection on its links with other countries. We find a text written by the theorists and practitioners of law, political science, international relations and history. Most of them refer to the current problems.

From the point of view of the current geopolitical situation, one should pay a special attention to the article about the crisis in Ukraine. Maria Gołda-Sobczak in her comprehensive work analyses the annexation of Crimea by Russia in March 2014. The author titled the text as a question: annexation or secession of Crimea? It can be concluded that she fully replied to this question. The greatest value of the text is that it showed the broad context of the whole case. As one of the few researchers could concisely and concretely show the outline of the history of the peninsula, to outline the political background and indicate the motivations that were behind the political decision makers, who brought as a consequence of the incorporation of the Crimea into the Russian Federation. These decision-makers are not only Russia but also Ukraine, the European Union, the OSCE and the NATO. Presenting their response to the conflict was as interesting as the point of view of Putin. The reader receives a comprehensive picture of the situation.

As usual in cases of collective works, not all articles provide such valuable knowledge as the one mentioned above. The reader may have the impression that certain texts do not refer to the main topic. In several articles there is missing methodology, summary and some analyses have not enough exhaustive conclusions. Some readers may alienate footnotes that in some chapters take up more space than the body text. This makes it difficult to understand the reading.

This book could be recommend ed particularly to theorists dealing with international relations, for whom the topics can be a perfect supplement to their own research. However, those who look for a comprehensive look at Russia's policies towards its neighbours will be disappointed. The book definitely enriches the current state of knowledge on the selected aspects of the eastern policy. It is also a good source of information for practitioners, who normally maintain political relations with the Russian Federation and its eastern neighbours. Therefore, the reviewed book is a valuable position for a Polish reader, as it explains Russia's history in a very comprehensive way and it fulfils its objectives - it presents the nation's history, symbols and emotional association that are crucial for understanding contemporary Russian politics. 


\section{References:}

Gardocki, S. (Ed.). Obszar byłego ZSRR. Klęska demokracji czy transformacja? Toruń: Wydawnictwo Adam Marszałek 2013.

Gardocki, S. (Ed.). Problemy polityczne i społeczne współczesnej Azji. Toruń: Wydawnictwo Adam Marszałek 2017.

Gardocki, S. (Ed.). Przemiany polityczno-społeczne w przestrzeni poradzieckiej. Toruń: Wydawnictwo Adam Marszałek 2016.

Gardocki, S. (Ed.). Rosja i jej sąsiedzi. Studia i szkice. Toruń: Wydawnictwo Adam Marszałek 2015.

Gardocki, S. (Ed.). Rosja. Ukraina. Białoruś. Wybrane dylematy rozwoju. Toruń: Wydawnictwo Adam Marszałek 2015.

\section{Author}

\section{Ms Ewelina Wojciechowska}

Nicolaus Copernicus University in Torun, Faculty of Political Science and International Studies

Contact details: ul. Garncarska 59, 97-320 Wolbórz, Poland

e-mail: ewelina.wojciechowska@hotmail.com 